\title{
PENGARUH BERMAIN OUTDOOR DAN KEGIATAN FINGER PAINTING TERHADAP KREATIVITAS ANAK USIA DINI
}

\author{
Rachma Hasibuan*) \\ rachmahasibuan@yahoo.com \\ Mallevi Agustin Ningrum**) \\ malleviningrum@yahoo.co.id
}

\begin{abstract}
Abstrak
Penelitian ini bertujuan untuk mengkaji pengaruh bermain outdoor dan kegiatan finger painting terhadap kreativitas anak usia dini khususnya anak di TK. Penelitian ini menggunakan pendekatan penelitian kuantitatif dengan metode penelitian eksperimen desain Pretest-Posttest Control Group Design dimana kelompok eksperimen diberikan perlakuan sedangkan kelompok kontrol tidak diberikan perlakuan.

Teknik pengumpulan datanya menggunakan observasi dan dokumentasi. Untuk menganalisis data pengujian hipotesis penelitian menggunakan program SPSS 20.0 for Windows Evaluation Version dengan teknik Anova 2 jalur (Uji F).

Berdasarkan hasil penelitian serta analisis data yang dilakukan dengan menggunakan Anova 2 jalur (Uji F), maka diperoleh sebagai berikut: (1) nilai $\mathrm{df}=1$ dan taraf signifikansi $\alpha=0,05$ diperoleh nilai koefisien $\mathrm{F}=2,134$ dan sig. $=0,107$, menunjukkan taraf signifikansi di atas $\alpha=$ 0,05 untuk pelaksanaan pembelajaran dengan bermain outdoor, (2) nilai $\mathrm{df}=1$ dan taraf signifikansi $\alpha=0,05$ diperoleh nilai koefisien $F=1,733$ dan sig. $=0,171$, menunjukkan taraf signifikansi di atas $\alpha=0,05$ untuk pelaksanaan pembelajaran dengan kegiatan finger painting, dan (3) nilai $\mathrm{df}=1$ dan taraf signifikansi $\alpha=0,05$ diperoleh nilai koefisien $\mathrm{F}=2,778$ dan sig. $=0,101$, menunjukkan taraf signifikansi di atas $\alpha=0,05$ untuk pelaksanaan pembelajaran dengan bermain outdoor dan kegiatan finger painting.
\end{abstract}

Kata-kata Kunci: bermain outdoor, finger painting, kreativitas anak.

\begin{abstract}
This study aimed to assess the effect of outdoor play and activities finger painting to the creativity of children in Kindergarten. This study uses a quantitative research approach with a model of experimental research methods pretest-posttest control group design. Observation techniques used in data collection and documentation.

While analyzing the data for the research hypothesis testing using SPSS 20.0 for Windows Evaluation Version with Anova technique lane 2 (Test $F$ ).

Based on the results of the study and data analysis performed using ANOVA 2 lines (Test F), it is obtained as follows: (1) the value of $d f=1$ and $\alpha=0.05$ significance level obtained coefficient $F$ $=2.134$ and sig. $=0.107$, suggesting above the significance level $\alpha=0.05$ for the implementation of learning with outdoor play, (2) the value of $d f=1$ and $\alpha=0.05$ significance level obtained coefficient $F=1.733$ and sig. $=0.171$, suggesting above the significance level $\alpha=0.05$ for the implementation of learning with finger painting activities, and (3) the value of $d f=1$ and $\alpha=0.05$ significance level obtained coefficient $F=2.778$ and sig. $=0.101$, suggesting above the significance level $\alpha=0.05$ for the implementation of learning with outdoor play and activities finger painting.
\end{abstract}

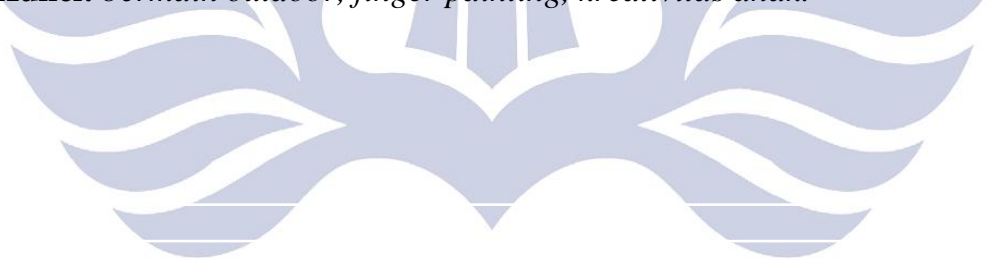

Key words: outdoor play, event painting with fingers, children's creativity.

*) dan **) : Dosen PGPAUD FIP Unesa 


\section{PENDAHULUAN}

Pendidikan anak usia dini adalah suatu upaya pembinaan yang ditujukan kepada anak sejak lahir sampai usia enam tahun yang dilakukan melalui pemberian rangsangan pendidikan untuk membantu pertumbuhan dan perkembangan jasmani dan rohani agar anak memiliki kesiapan dalam memasuki pendidikan lebih lanjut (Kemdiknas (2010:1). Pendidikan anak usia dini diselenggarakan sebelum jenjang pendidikan dasar melalui jalur pendidikan formal, nonformal, dan informal. Pendidikan anak usia dini pada jalur pendidikan formal berbentuk Taman Kanak-kanak (TK), Raudhatul Athfal (RA), atau bentuk lain yang sederajat.

TK merupakan salah satu bentuk satuan pendidikan anak usia dini pada jalur pendidikan formal yang menyelenggarakan program pendidikan bagi anak usia empat tahun sampai enam tahun (Depdiknas, 2005:40). Sedangkan menurut Aqib (2009:9), TK adalah pendidikan anak usia dini yang ditujukan bagi anak usia 4-6 tahun sebelum memasuki pendidikan dasar. Tujuan dari penyelenggaraan TK adalah membantu meletakkan dasar ke arah perkembangan sikap, perilaku, pengetahuan, keterampilan, dan daya cipta anak didik untuk pertumbuhan serta perkembangan selanjutnya.

Masa usia 4-6 tahun diidentikkan sebagai masa usia dini karena pada saat ini anak sudah dianggap cukup mampu untuk mengerjakan tugas-tugas yang diberikan baik secara fisik maupun mental. Mengingat perkembangan utama yang terjadi selama masa usia dini sering disebut sebagai usia penjelajah yaitu masa penguasaan dan pengendalian lingkungan. Maka, pada masa ini anak-anak ingin selalu mengetahui keadaan lingkungannya, bagaimana mekanisme kerja dari sesuatu, bagaimana perasaannya, dan bagaimana anak mampu menjadi bagian dari lingkungan. Setiap anak dilahirkan dengan keunikan sendiri, mereka memiliki kemampuan atau keterampilan yang berbeda-beda antara yang satu dengan yang lainnya, sehingga anak telah membawa sejumlah potensi yang terdapat dalam dirinya. Potensi tersebut meliputi berbagai imajinasi yang menjadikan kreativitas anak menjadi berkembang.

Kreativitas anak sangat penting untuk dikembangkan karena anak usia 5-6 tahun memang sangat aktif dalam bergerak dan memerlukan berbagai stimulasi positif. Hal itu sesuai dengan teori Maria Montessori yang menekankan bahwa usia lahir sampai enam tahun merupakan masa peka, di mana dalam masa peka tersebut merupakan masa yang sangat baik dalam mengembangkan setiap potensi perkembangan yang dimiliki oleh anak, sehingga diperlukan kondisi dan stimulasi yang sesuai dengan kebutuhan pertumbuhan dan perkembangan anak.

Menurut Montessori (dalam Feez ,2010:8) menyatakan bahwa

"In the Montessori tradition these periods, signal the opening of windows of developmental opportunity. During these transient periods of heightened interest children tend to focus their attention on particular object and activities, while ignoring other aspects of the environment. Each special interest is so intense that 'it leads its possessor to perform a certain series of actions...with an outpouring of energy incredible to us"

Pernyataan tersebut dapat diartikan bahwa "anak harus diberikan kesempatan dan kebebasan dalam bergerak serta mengamati benda-benda yang ada di sekitar melalui kehidupannya sehari-hari”.

Sama halnya dengan teori Johann Heinrich Pestalozzi yang menekankan pentingnya kemerdekaan dan kebebasan batin anak dari segala tekanan di lingkungannya agar anak dapat belajar dan berpikir secara optimal, menyarankan agar anak belajar dari benda-benda riil dan memasukkan unsur kegiatan bermain sebagai bagian dari pendidikan TK (Suyanto, 2005:17).

Satu hal yang cukup menonjol pada masa ini adalah munculnya berbagai bentuk kreativitas dalam bermain, sehingga periode ini seringkali dinamakan sebagai masa kreatif. Kreativitas yang ditunjukkan anak pada masa ini merupakan bentuk kreativitas yang original dengan frekuensi kemunculannya yang seolah tanpa terkendali dibandingkan dengan masamasa lain dalam kehidupan seorang anak setelah masa ini berlalu (Kemdiknas, 2010:5).

Menurut Sujiono (2010:13), kreativitas pada setiap anak perlu dikenali, dipupuk, dan dikembangkan melalui stimulasi yang tepat agar kreativitas anak dapat terwujud. Potensi kreatif yang terdapat dalam diri setiap individu dapat diobservasi saat anak melakukan kegiatan bermain, karena bermain adalah dunia anak dan umumnya terjadi secara alamiah. Melalui kegiatan bermain, anak mampu mengembangkan potensi yang tersembunyi di dalam dirinya secara aman, nyaman, dan menyenangkan.

Guilford menyatakan bahwa kreativitas mengacu pada kemampuan yang menandai ciri-ciri seorang kreatif. Guilford mengemukakan dua cara berpikir, yaitu cara berpikir konvergen dan divergen. Cara berpikir konvergen adalah cara-cara individu dalam memikirkan sesuatu dengan pandangan bahwa hanya ada satu jawaban yang benar. Sedangkan cara berpikir divergen adalah kemampuan individu untuk mencari 
berbagai alternatif jawaban terhadap suatu persoalan (Sulistyorini, 2011:3).

Munandar (2009:12) mendefinisikan kreativitas sebagai kemampuan untuk membuat kombinasikombinasi baru, asosiasi baru berdasarkan bahan, informasi, data atau elemen-elemen yang sudah ada sebelumnya menjadi hal-hal yang bermakna dan bermanfaat. Jadi kreativitas merupakan aktivitas imajinatif yang hasilnya merupakan pembentukan kombinasi dari informasi yang diperoleh dari pengalaman-pengalaman sebelumnya menjadi hal yang baru, berarti dan bermanfaat.

Chikszentmihalyi (dalam Suharnan ,2011:6), kreativitas didefinisikan sebagai setiap tindakan, gagasan (ide), atau hasil karya (produk) yang mengubah kawasan (domain) yang telah ada, atau mentransformasikan kawasan yang telah ada untuk menjadi suatu kawasan yang baru. Dengan demikian, orang kreatif adalah orang yang berpikir dan bertindak untuk mengubah suatu kawasan atau membangun kawasan baru.

Seseorang dikatakan kreatif apabila menghasilkan suatu penyelesaian atau karya yang mengandung unsur tidak lazim dan berguna atau bernilai. Dengan demikian, kreativitas didefinisikan menurut dua aspek yang menjadi konsekuensinya dan bukan bagaimana proses menuju konsekuensi itu (Halpern dalam Suharnan, 2011:7).

Dari penjelasan di atas, dapat disimpulkan definisi kreativitas dapat dikelompokkan menjadi dua, yaitu: (1) kreativitas sebagai proses kreatif yang artinya apa saja sumber-sumber kemampuan seseorang dan aktivitas yang berpotensi besar untuk melahirkan gagasan-gagasan baru; (2) kreativitas sebagai hasil karya kreatif yang artinya potensi kreatif yang dimiliki seseorang belum tentu teraktualisasikan dalam bentuk perilaku yang dapat menghasilkan karya-karya baru yang berguna bagi lingkungan. Oleh karena itu, jika seseorang melihat fenomena kreativitas, maka lebih baik melalui karya-karya nyata yang telah dihasilkan seseorang daripada melihat bagaimana proses menghasilkan karya-karya tersebut.

Meskipun terdapat dua pandangan yang berbeda penekanan tentang definisi kreativitas, namun terdapat kesamaan pandangan yang penting. Kreativitas harus memiliki aspek baru, apakah berupa gagasan, pemikiran, aktivitas, tindakan ataupun hasil karya (produk) dan memiliki nilai kegunaan.

Kegiatan bermain outdoor mampu memberikan suasana yang berbeda bagi anak dan lebih mendekatkan anak pada alam sekitar. Sesuai dengan teori Pestalozzi (dalam Kemdiknas, 2010:12-13) yang menekankan pada pengamatan alam. Alam sebagai sumber utama pengetahuan. Oleh karena itu, kegiatan belajar dilakukan melalui pengamatan-pengamatan di luar ruangan agar anak memperoleh berbagai macam pengetahuan. Salah satu pengetahuan yang dapat berkembang adalah potensi kreatif yang terdapat dalam diri setiap individu anak.

Potensi kreatif tersebut dapat diobservasi saat anak melakukan kegiatan bermain, karena bermain adalah dunia anak dan umumnya terjadi secara alamiah. Melalui kegiatan bermain, anak mampu mengembangkan potensi yang tersembunyi di dalam dirinya secara aman, nyaman, dan menyenangkan. Kegiatan bermain tersebut akan lebih bermakna dan menyenangkan bagi anak apabila dilakukan di luar ruangan (outdoor) karena pengetahuan anak akan menjadi lebih luas dan berkembang karena anak dapat menemukan sesuatu yang tidak ada ketika sedang bermain di dalam ruangan. Untuk itu, diperlukan berbagai macam kegiatan bermain yang dapat menstimulasi anak untuk beraktivitas dan memilih kegiatannya sendiri sehingga mampu menemukan halhal yang baru dan dapat berpikir kreatif untuk memecahkan berbagai permasalahan yang dihadapi oleh anak.

Hal tersebut sesuai dengan teori yang dikemukakan oleh Vygotsky (dalam Sujiono, 2009:114-115) bahwa anak merupakan pembelajar yang aktif sehingga pengetahuannya tidak dapat diperoleh dengan cara dialihkan dari orang lain, melainkan merupakan sesuatu yang dibangun dan diciptakan sendiri oleh anak sehingga peran orang dewasa adalah memberikan scaffolding atau bantuan untuk memfasilitasi perkembangan anak.

Keseluruhan waktu bermain anak dilakukan melalui kegiatan akademik, sedikit sekali kegiatan dalam bentuk bermain. Kegiatan bermain sambil belajar di TK sangat jauh dari kesan bermain yang menyenangkan, karena kegiatannya monoton dengan buku-buku penunjang. Sehingga anak-anak cenderung mendapatkan kegiatan yang tidak sesuai dengan minat dan kebutuhannya karena harus mengikuti kegiatan yang diberikan oleh guru. Akibatnya, kebutuhan dasar bermain yang berkaitan dengan kegiatan perkembangan baik emosi, sosial, fisik motorik, bahasa, dan kreativitas anak cenderung terabaikan.

Penerapan proses pembelajaran di TK dominan menggunakan strategi konvensional dan paradigma lama, segala kegiatan pembelajaran terpusat pada guru sedangkan anak tidak dilibatkan secara langsung untuk ambil bagian beraktivitas.

Untuk itu diperlukan berbagai macam permainan yang dapat menstimulasi anak untuk beraktivitas dan memilih kegiatannya sendiri sehingga mampu 
menemukan hal-hal yang baru dan dapat berpikir kreatif untuk memecahkan berbagai permasalahan yang dihadapi oleh anak. Banyak kegiatan bermain yang dapat mengoptimalkan setiap potensi yang dimiliki oleh anak tanpa harus memaksakan anak ke dalam bentuk pembelajaran yang akademik, salah satunya adalah bermain di lingkungan outdoor (luar ruangan) dan kegiatan finger painting.

Bermain outdoor sangat baik bagi pengembangan potensi anak, baik motorik kasar-motorik halus, sosial, kognitif, kemandirian, dan kreativitas anak.

Kebebasan diperlukan agar anak dapat memilih apa yang paling berguna dan paling menarik dalam berbagai hal dari semua materi dan pengalaman yang ditawarkan. Sebagai gantinya, orang dewasa mengamati minat dan kegiatan anak, memperoleh wawasan dalam kepribadian dan perkembangan anak, dan menyesuaikan atau memodifikasi lingkungan untuk memenuhi kebutuhan anak (Johnson dan Roopnarine, 2011:389).

Di luar kelas, anak-anak dapat mempelajari berbagai hal serta mengoptimalkan semua aspek perkembangannya. Guru dapat membantu anak dalam meningkatkan pertumbuhan anak melalui berbagai macam program kegiatan yang dapat dievaluasi melalui pengamatan ataupun berinteraksi langsung dengan anak (Asmawati, 2008:4.1).

Begitu pula pada kegiatan finger painting yang merupakan kegiatan yang menarik untuk diberikan kepada anak usia 5-6 tahun karena anak lebih memperoleh kesempatan untuk membangun pengetahuan dan pengalaman mereka sendiri tanpa adanya paksaan dan doktrin dari guru. Di samping itu, kegiatan finger painting bagi anak memerlukan waktu yang lumayan banyak dan persiapannya juga cenderung kompleks, sehingga kegiatan finger painting jarang diberikan oleh guru pada waktu kegiatan bermain di ruang kelas.

Nugroho (2012:51) mengemukakan bahwa finger painting adalah cara awal melukis dengan menggunakan tangan sebagai alat lukis dan menggunakan kertas yang permukaannnya halus dan agak tebal dengan penggunaan warna-warna asli seperti merah, kuning, biru, putih, dan hitam untuk memberikan pengalaman belajar dan bereksplorasi kepada anak.

Menurut Hildebrand dalam Moeslichatoen (2005:35), menggambar dengan jari menggunakan tepung kanji merupakan perantara untuk menyalurkan kreativitas dan bermain kotor karena gambar atau lukisan yang dihasilkan dapat dibuat, dihapus, dan dibuat lagi. Secara simbolik, permasalahan pribadi dapat diungkapkan lalu dihapuskan dengan satu sapuan jari-jari tangan. Hal ini menunjukkan bahwa melukis dengan jari mempunyai nilai teurapetis.

Finger painting, yaitu teknik melukis dengan jari tangan secara langsung tanpa menggunakan bantuan alat. Dengan demikian, anak dapat mengganti kuas dengan jari-jari tangannya secara langsung (Pamadhi dan Sukardi, 2010:3.35).

Pablo Picasso (dalam Khodijah dan Wismiarti, 2010:22) mengemukakan bahwa "sebaiknya orang dewasa tidak boleh mengajar anak-anak menggambar, bahkan semestinya belajar dari mereka". Dengan kata lain, hendaknya kita harus mendukung kreativitas awal mereka dengan jalan membiarkan mereka melukis apa saja yang mereka kehendaki tanpa memberikan saran atau mengajarkan aturan dalam melukis. Sesungguhnya anak seringkali mengagumkan dan anak mampu menciptakan sesuatu secara alamiah.

Kegiatan finger painting dapat dilakukan di luar ruangan kelas (outdoor). Hal itu mampu memberikan suasana yang berbeda bagi anak dan lebih mendekatkan anak pada alam sekitar sehingga objek yang dilukis oleh anak menjadi lebih bervariasi. Sesuai dengan teori Pestalozzi (dalam Kemdiknas , 2010:1213) yang menekankan pada pengamatan alam. Alam sebagai sumber utama pengetahuan. Oleh karena itu, kegiatan belajar dilakukan melalui pengamatanpengamatan di luar ruangan agar anak memperoleh berbagai macam pengetahuan.

Hal itu sesuai dengan kajian empirik dari Masiming (2005) yang menyimpulkan bahwa secara keseluruhan hasil tes kreativitas menunjukkan peningkatan dan pengaruh yang signifikan setting ruang bermain terhadap peningkatan kreativitas pada anak usia dini.

Pengaruh kegiatan finger painting telah dibuktikan dari berbagai penelitian di antaranya dilakukan oleh Andrimeda (2012), Martono dan Retnowati (2007), dan Nur Hidayati (2012).

Pada intinya dapat diketahui bahwa anak yang kreatif akan belajar dan bermain dengan caranya masing-masing untuk mengungkapkan setiap ide kreatif yang dimilikinya menjadi sebuah bentuk lukisan yang dilakukan setelah kegiatan bermain outdoor (di luar ruangan).

Bertitik tolak pada uraian di atas, tentunya kegiatan bermain outdoor sangat cocok apabila dilakukan dengan kegiatan finger painting, karena anak akan melihat sesuatu yang lain dari biasanya ketika berada di luar ruangan dan lebih memberikan pengalaman yang berbeda kepada anak. Selain itu, anak juga dapat mendapatkan kebebasan dan kesempatan yang luas untuk bereksplorasi dengan benda-benda yang ditemuinya dan melukiskan apa yang diihatnya di 
luar ruangan tersebut menjadi bentuk hasil karya yang kreatif.

Hal itu sesuai teori Frederich Wilhelm Froebel (dalam Wijana, 2010:219) bahwa anak harus dibiarkan sendiri secara aktif untuk mengamati hal-hal yang ada di sekitarnya menggunakan panca indera dan memberikan suasana yang bebas dan merdeka sehingga anak mampu berkembang sesuai dengan potensinya masing-masing.

Atas dasar itu, maka rumusan masalah dalam penelitian ini adalah: (1) apakah bermain outdoor berpengaruh terhadap kreativitas anak TK ?; (2) apakah kegiatan finger painting berpengaruh terhadap kreativitas anak TK ?; (3) apakah bermain outdoor dan kegiatan finger painting berpengaruh secara bersamasama terhadap kreativitas anak TK ?.

Tujuan penelitian ini adalah: (1) mengkaji pengaruh bermain outdoor terhadap kreativitas anak TK; (2) mengkaji pengaruh kegiatan finger painting terhadap kreativitas anak TK; (3) mengkaji pengaruh bermain outdoor dan kegiatan finger painting secara bersama-sama terhadap kreativitas anak TK .

\section{METODE PENELITIAN}

Jenis penelitian ini adalah penelitian eksperimen karena bertujuan untuk mengukur pengaruh variabel bebas yaitu bermain outdoor $\left(\mathrm{X}_{1}\right)$ dan kegiatan finger painting $\left(\mathrm{X}_{2}\right)$ terhadap variabel terikat yaitu kreativitas anak (Y), dengan menggunakan pendekatan penelitian kuantitatif.

Penelitian kuantitatif adalah penelitian yang berlandaskan pada filsafat positivisme, digunakan untuk meneliti pada populasi atau sampel tertentu, teknik pengambilan sampel pada umumnya dilakukan secara random, pengumpulan data menggunakan instrumen penelitian, analisis data bersifat kuantitatif atau statistik dengan tujuan untuk menguji hipotesis yang telah ditetapkan (Sugiyono: 2009:14).

Penelitian eksperimen ini menggunakan PretestPosttest Control Group Design.

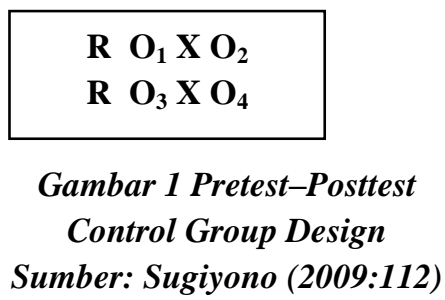

Penelitian ini menggunakan sampel yang telah ditentukan dan telah terpilih 3 lembaga TK yaitu:
Tabel 1 Sampel Penelitian

\begin{tabular}{|c|c|c|}
\hline Nama TK & $\begin{array}{c}\text { Jumlah } \\
\text { Anak }\end{array}$ & Keterangan \\
\hline $\begin{array}{c}\text { TK Tunas } \\
\text { Harapan I } \\
\text { Tunggunjagir }\end{array}$ & 31 anak & $\begin{array}{c}\text { Kelompok } \\
\text { Kontrol }\end{array}$ \\
\hline $\begin{array}{c}\text { TK Mekarsari } \\
\text { Sukosari }\end{array}$ & 16 anak & $\begin{array}{l}\text { Kelompok } \\
\text { Eksperimen }\end{array}$ \\
\hline $\begin{array}{c}\text { TK Putra } \\
\text { Harapan Rumpuk }\end{array}$ & 15 anak & $\begin{array}{c}\text { Kelompok } \\
\text { Eksperimen }\end{array}$ \\
\hline Jumlah & 62 anak & \\
\hline
\end{tabular}

Dalam desain ini terdapat dua kelompok yang dipilih secara random, kemudian diberi perlakuan awal untuk mengetahui keadaan awal antara kelompok eksperimen dengan kelompok kontrol. Hasil perlakuan awal yang baik apabila nilai kelompok eksperimen tidak berbeda secara signifikan. Pengaruh perlakuan adalah (O2-O1) (Sugiyono, 2009:113).

Maksud dari desain penelitian ini adalah ada dua kelompok yang dipilih secara random. Terlebih dahulu kelompok eksperimen dan kelompok kontrol diberikan perlakuan awal berupa kegiatan menggambar bebas dengan krayon dan tempat bermain indoor untuk mengetahui keadaan awal di setiap kelompok tersebut. Setelah itu, diberikan perlakuan penelitian berupa bermain outdoor dan kegiatan finger painting kepada kelompok eksperimen kemudian dilakukan pengukuran. Untuk kelompok kontrol tidak diberikan perlakuan bermain outdoor dan kegiatan finger painting kemudian dilakukan pengukuran.

Teknik pengumpulan datanya menggunakan observasi dan dokumentasi. Observasi dilakukan untuk melihat secara langsung dan memperoleh data tentang aktivitas anak dan guru dalam mengembangkan kreativitas yang dimiliki oleh anak melalui lembar observasi untuk mengukur hal-hal sebagai berikut: (1) aktivitas guru dalam kegiatan bermain outdoor; (2) aktivitas anak dalam kegiatan bermain outdoor; (3) aktivitas guru dalam kegiatan finger painting; (3) aktivitas anak dalam kegiatan finger painting; (4) proses kreativitas anak dalam menciptakan produk hasil karya sebagai ungkapan kreatif dan ide original yang dimiliki oleh anak.

Sedangkan dokumentasi untuk memperoleh data tentang proses dan hasil kegiatan pembelajaran yang telah dilakukan berupa: (1) perangkat pembelajaran berupa RKM, RKH, dan langkah-langkah pembelajaran untuk memperoleh data tentang keberhasilan kegiatan pembelajaran yang telah dilakukan. Pengumpulan data dilakukan pada saat proses pembelajaran sudah berlangsung; (2) portofolio 
hasil karya anak dalam kegiatan melukis dengan jari untuk mendapatkan data tentang pencapaian hasil kreativitas anak selama mengikuti kegiatan pembelajaran. Pengumpulan data dilakukan pada saat proses pembelajaran sudah berlangsung. Cizek (dalam Yus, 2011:90) menyatakan bahwa portofolio adalah pengumpulan informasi tingkat tinggi yang berkenaan dengan kemajuan belajar anak sehingga guru dapat lebih cermat menilai murid dan penilaian lebih erat kaitannya dengan pembelajaran. Dalam situasi tersebut guru menggunakan portofolio (kumpulan pekerjaan anak) untuk mengakses murid, sedangkan murid menggunakannya untuk melihat kembali kegiatan dan hasil belajar yang telah diraihnya; (3) kamera digital untuk mendokumentasikan aktivitas guru dan anak dalam proses pembelajaran bermain outdoor dan kegiatan finger painting untuk mendapatkan data tentang keberhasilan proses pembelajaran yang telah dilakukan oleh guru dan anak serta mendokumentasikan hasil karya kreatif yang diciptakan oleh anak.

Validitas instrumen penelitian dilakukan setelah validasi instrumen di lapangan (validitas empirik), maka data yang diperoleh kemudian dianalisis dengan menggunakan tes Pearson Correlation Sig. (2-tailed) melalui bantuan program SPSS 20.0 for Windows Evaluation Version.

Sedangkan untuk mengukur reliabilitas instrumen penelitian berupa lembar observasi dan format penilaian hasil karya anak menggunakan Cronbach's Alpha melalui bantuan SPSS 20.0 for Windows Evaluation Version.

Teknik analisis data yang diterapkan dalam uji hipotesis penelitian ini adalah menggunakan Analysis of Variance (Anova) 2 jalur. Data yang telah diperoleh dari hasil penelitian akan diuji menggunakan Anova 2 jalur setelah memenuhi syarat uji normalitas dan homogenitas untuk melihat apakah terdapat interaksi antara kegiatan bermain outdoor dan kegiatan finger painting terhadap kreativitas anak

Uji normalitas menggunakan komputerisasi program SPSS 20.0 for Windows Evaluation Version yaitu melalui tes Kolmogorov-Smirnov. Adapun kriteria sebaran data menunjukkan normal jika Lh > 0,05 .

Sedangkan untuk uji homogenitas digunakan aplikasi program SPSS 20.0 for Windows Evaluation Version yaitu melalui output Levene's Test of Equality of Error Variance.

\section{HASIL DAN PEMBAHASAN}

Sebelum melakukan uji terhadap hipotesis penelitian, terlebih dahulu diadakan analisis data tentang kreativitas anak (variabel Y) dengan variabel bebas meliputi penerapan pembelajaran dengan kegiatan bermain outdoor $\left(\mathrm{X}_{1}\right)$ dan kegiatan finger painting $\left(\mathrm{X}_{2}\right)$.

Hipotesis dalam penelitian ini dilakukan secara berurutan sesuai analisis yang diterapkan dalam teknik analisis varian dua jalur, yaitu analisis variabel secara parsial dan analisis secara interaksi antar kelompok. Selanjutnya dasar atau kriteria pengujian terhadap hipotesis-hipotesis ditetapkan taraf signifikansi $\alpha=$ 0,05 .

Untuk menguji hipotesis-hipotesis tersebut menggunakan teknik analisis varian dua jalur melalui program SPSS Versi 20.0 dapat dikemukakan sebagai berikut:

Hipotesis 1:

$\mathrm{Ho}=$ diterima, jika Fo $<\mathrm{Ft}$

$\mathrm{Ho}=$ ditolak, jika Fo $>\mathrm{Ft}$

Hipotesis 2:

$\mathrm{Ho}=$ diterima, jika $\mathrm{Fo}<\mathrm{Ft}$

$\mathrm{Ho}=$ ditolak, jika $\mathrm{Fo}>\mathrm{Ft}$

Hipotesis 3:

$\mathrm{Ho}=$ diterima, jika $\mathrm{Fo}<\mathrm{Ft}$

$\mathrm{Ho}=$ ditolak, jika $\mathrm{Fo}>\mathrm{Ft}$

Selanjutnya untuk uji hipotesis tersebut dengan teknik analisis varian dua jalur menggunakan dasar yaitu hipotesis nihil (Ho) ditolak jika taraf signifikansi (Sig.) $<\alpha=0,05$. Setelah dianalisis dengan menggunakan program SPSS Versi 20.0 dapat dikemukakan sebagai berikut:

a. Hipotesis 1

Ho :

"Tidak ada pengaruh bermain outdoor terhadap kreativitas anak TK

Ha :

"Ada pengaruh bermain outdoor terhadap kreativitas anak TK. Dari hasil uji hipotesis 1 di atas menggunakan teknik analisis varian dengan $\mathrm{df}$ $=1$ dan taraf signifikansi $\alpha=0,05$ diperoleh nilai koefisien $\mathrm{F}=2,134$ dan sig. $=0,107$, menunjukkan taraf signifikansi di atas $\alpha=0,05$

Dengan demikian hasil uji terhadap hipotesis ke-1 menolak Ho dan menerima Ha. Jadi dalam penelitian ini dapat disimpulkan bahwa ada pengaruh bermain outdoor terhadap kreativitas anak TK.

b. Hipotesis 2

Ho :

"Tidak ada pengaruh kegiatan finger painting terhadap kreativitas anak TK. 
Ha :

"Ada pengaruh finger painting terhadap kreativitas anak TK. Dari hasil uji hipotesis 1 di atas menggunakan teknik analisis varian dengan $\mathrm{df}=1$ dan taraf signifikansi $\alpha=0,05$ diperoleh nilai koefisien $\mathrm{F}=1,733$ dan sig. $=0,171$, menunjukkan taraf signifikansi di atas $\alpha=0,05$.

Dengan demikian hasil uji terhadap hipotesis ke-1 menolak Ho dan menerima Ha. Jadi dalam penelitian ini dapat disimpulkan bahwa ada pengaruh kegiatan finger painting terhadap kreativitas anak TK.

c. Hipotesis 3

Ho :

"Tidak ada pengaruh secara bersama-sama bermain outdoor dan kegiatan finger painting terhadap kreativitas anak TK

$\mathrm{Ha}$ :

"Ada pengaruh secara bersama-sama bermain outdoor dan kegiatan finger painting terhadap kreativitas anak TK Dari hasil uji hipotesis $1 \mathrm{di}$ atas menggunakan teknik analisis varian dengan $\mathrm{df}=1$ dan taraf signifikansi $\alpha=0,05$ diperoleh nilai koefisien $\mathrm{F}=2,778$ dan sig. $=0,101$, menunjukkan taraf signifikansi di atas $\alpha=0,05$. Dengan demikian hasil uji terhadap hipotesis ke-1 menolak Ho dan menerima Ha.

Jadi dalam penelitian ini dapat disimpulkan bahwa ada pengaruh secara bersama-sama bermain outdoor dan kegiatan finger painting terhadap kreativitas anak TK

Bertolak dari hasil pengujian terhadap hipotesis dengan statistik analisis varian dua jalur dapat diinterpretasikan bahwa kegiatan bermain outdoor berpengaruh terhadap kreativitas anak TK, kegiatan finger painting berpengaruh terhadap kreativitas anak TK, serta kegiatan bermain outdoor dan kegiatan finger painting berpengaruh secara bersama-sama terhadap kreativitas anak TK.

Hal ini terbukti dari hasil uji hipotesis yang menyatakan secara signifikan ada perbedaan pengaruh kelompok eksperimen dan kelompok kontrol. Dari pembuktian tersebut ternyata kreativitas anak dari kelompok eksperimen lebih meningkat dibandingkan dengan kelompok kontrol. Demikian pula dapat dikatakan bahwa selain meningkat, kreativitas anak juga dipengaruhi berkembang pesat.

Berdasarkan uraian dari hasil penelitian dan uji hipotesis yang telah diuraikan sebelumnya membuktikan bahwa: (1) pembelajaran dengan menggunakan kegiatan bermain outdoor secara signifikan mempunyai pengaruh lebih tinggi dalam pencapaian kreativitas dibandingkan dengan pembelajaran tanpa kegiatan bermain outdoor.

Dari hasil penelitian tersebut di atas sesuai dengan hasil temuan yang dilakukan oleh Masiming (2005) yang menyimpulkan bahwa secara keseluruhan hasil tes kreativitas menunjukkan peningkatan dan pengaruh yang signifikan setting ruang bermain terhadap peningkatan kreativitas pada anak usia dini.

Kegiatan bermain outdoor dalam penelitian ini juga mendukung teori Pestalozzi. Sesuai dengan teori Pestalozzi (dalam Kemdiknas, 2010:12-13) yang menekankan pada pengamatan alam. Alam sebagai sumber utama pengetahuan. Oleh karena itu, kegiatan belajar dilakukan melalui pengamatan-pengamatan di luar ruangan agar anak memperoleh berbagai macam pengetahuan. Untuk itu, kegiatan bermain outdoor mampu memberikan suasana yang berbeda bagi anak dan lebih mendekatkan anak pada alam sekitar sehingga objek yang dilukis oleh anak menjadi lebih bervariasi; (2) Hal ini juga membuktikan bahwa pembelajaran dengan menggunakan kegiatan finger painting secara signifikan mempunyai pengaruh lebih tinggi dalam pencapaian kreativitas dibandingkan dengan pembelajaran tanpa kegiatan finger painting.

Hasil penelitian tersebut senada dengan beberapa penemuan terdahulu yaitu: (a) penelitian Martono dan Retnowati (2007) mengemukakan bahwa pembelajaran seni lukis menggunakan tema yang sesuai dengan pilihan anak sendiri agar anak menjadi senang dan dapat mengembangkan kreativitasnya; (b) penelitian Nur Hidayati (2012) menyimpulkan bahwa finger painting dapat meningkatkan pembelajaran seni untuk anak usia 5-6 tahun.

Hasil dari penelitian ini juga mendukung teori dari Froebel dan Montessori. Dasar utama untuk mempelajari pengetahuan dan kecekatan adalah keaktifan anak itu sendiri. Cara mendidik yang baik menurut teori Froebel adalah dengan metode yang banyak memberikan kesempatan kepada anak untuk sibuk dan aktif mengerjakan, membuat, dan menciptakan sesuatu atas inisiatif sendiri (ekspresi), sedangkan Montessori mengungkapkan bahwa kebebasan diperlukan agar anak dapat memilih apa yang paling berguna dan paling menarik dalam berbagai hal dari semua materi dan pengalaman yang ditawarkan. Sebagai gantinya, orang dewasa mengamati minat dan kegiatan anak, memperoleh wawasan dalam kepribadian dan perkembangan anak, dan menyesuaikan atau memodifikasi lingkungan untuk memenuhi kebutuhan anak (Johnson dan Roopnarine, 2011:389); (3) kreativitas anak yang mengikuti kegiatan bermain outdoor dan kegiatan finger painting secara signifikan menunjukkan adanya 
perbedaan dengan kreativitas anak yang tidak mengikuti kegiatan bermain outdoor dan kegiatan finger painting.

Hal ini membuktikan bahwa pembelajaran dengan menggunakan kegiatan bermain outdoor dan kegiatan finger painting secara signifikan mempunyai pengaruh lebih tinggi dalam pencapaian kreativitas dibandingkan dengan pembelajaran tanpa kegiatan bermain outdoor dan kegiatan finger painting.

Hasil penelitian ini juga mendukung beberapa penemuan terdahulu yaitu: (1) penelitian yang dilakukan oleh Ayan (dalam Rachmawati dan Kurniati, 2010) menyimpulkan bahwa kreativitas mulai hilang pada masa kanak-kanak menuju masa dewasa; (2) penelitian Buzan (dalam Suharnan, 2011) menyimpulkan bahwa sejalan dengan pertambahan usia seseorang, maka pemikiran yang original makin menghilang dan digantikan oleh kesibukan yang menuntut produktivitas; (3) penelitian Karmila (2011) menyimpulkan bahwa metode permainan bahasa terbukti berpengaruh secara signifikan terhadap peningkatan kreativitas anak. Hal tersebut terbukti dari perbedaan secara signifikan pada tingkat kreativitas anak antara kelompok eksperimen yang diberikan perlakuan dengan kelompok kontrol tanpa diberikan perlakuan metode permainan bahasa; (4) penelitian Khasanah (2011) menyimpulkan bahwa permainan tradisional dapat menjadi media atau sarana untuk menstimulasi setiap aspek perkembangan anak usia dini khususnya usia 4-6 tahun.

Kreativitas anak dalam penelitian ini juga mendukung teori Lev Vygotsky. Vygotsky (dalam Sujiono, 2009:114-115) berpendapat bahwa anak merupakan pembelajar yang aktif sehingga pengetahuannya tidak dapat diperoleh dengan cara dialihkan dari orang lain, melainkan merupakan sesuatu yang dibangun dan diciptakan sendiri oleh anak sehingga peran orang dewasa adalah memberikan scaffolding atau bantuan untuk memfasilitasi perkembangan anak.

Untuk itu, dapat diketahui bahwa anak yang kreatif akan belajar dan bermain dengan caranya masingmasing untuk mengungkapkan setiap ide kreatif yang dimilikinya menjadi sebuah bentuk lukisan dengan finger painting yang dilakukan setelah kegiatan bermain outdoor (di luar ruangan) yang menyenangkan bagi anak.

\section{PENUTUP}

\section{Simpulan}

Adapun simpulan dalam penelitian ini adalah: (1) bermain outdoor berpengaruh terhadap kreativitas anak, terbukti dari kelompok yang dibelajarkan menggunakan kegiatan bermain outdoor kreativitasnya lebih baik daripada kelompok yang tidak dibelajarkan dengan menggunakan kegiatan bermain outdoor; (2) kegiatan finger painting berpengaruh terhadap kreativitas anak TK kelompok B di Kabupaten Lamongan, terbukti dari kelompok yang dibelajarkan menggunakan kegiatan finger painting kreativitasnya lebih baik daripada kelompok yang tidak dibelajarkan dengan menggunakan kegiatan finger painting; (3) bermain outdoor dan kegiatan finger painting secara bersama-sama berpengaruh terhadap kreativitas anak TK, terbukti dari kelompok yang dibelajarkan menggunakan kegiatan bermain outdoor dan finger painting kreativitasnya lebih baik daripada kelompok yang tidak dibelajarkan dengan bermain outdoor dan kegiatan finger painting.

\section{Saran}

Saran yang dapat diberikan dalam penelitian ini adalah: (1) hasil penelitian ini diharapkan dapat menjadi tindak lanjut atau bahan pertimbangan bagi pendidik PAUD lainnya yang akan melakukan penelitian dengan materi pembelajaran yang sama; (2) hasil penelitian ini dapat digunakan sebagai referensi bagi pendidik PAUD yang lain agar dapat memanfaatkan sumber belajar atau media pembelajaran yang ada di sekeliling anak; (3) bagi peneliti lanjutan hendaknya mampu menganalisis kekurangan dan kelebihan yang terjadi selama kegiatan penelitian berlangsung berdasarkan kenyataan yang ada di lapangan.

\section{DAFTAR PUSTAKA}

Aqib, Zainal. 2009. Belajar dan Pembelajaran $d i$ Taman Kanak-kanak. Bandung: Yrama Widya.

Asmawati, Lilik, dkk. 2008. Pengelolaan Kegiatan Pengembangan Anak Usia Dini. Jakarta: Universitas Terbuka.

Depdiknas. 2005. Pedoman Pembelajaran di Taman Kanak-kanak. Jakarta: Depdiknas.

Feez, Susan. 2010. Montessori and Early Childhood. London: Sage Publications.

Hidayati, Nur. 2012. Upaya Meningkatkan Seni melalui Finger Painting pada Kelompok B Tarbiyatul Athfal Al Islam Mejasem Kecamatan Kemangkon Kabupaten Purbalingga. Skripsi tidak diterbitkan. Purwokerto: PG PAUD Universitas Muhammadiyah Purwokerto. 
Johnson, James E dan Roopnarine, Jaipaul L. 2011. Pendidikan Anak Usia Dini dalam Berbagai Pendekatan Edisi Kelima. Jakarta: Kencana Prenada Media Group.

Karmila, Suharno, dan Purwadi. 2011. Jurnal Penelitian PAUDIA Vol. 1 No. 1. Pengaruh Metode Pembelajaran Permainan Bahasa terhadap Peningkatan Kretivitas Anak. (http://jurnal_penelitian_kreativitas_anak.html, diakses 10 September 2012).

Kemdiknas. 2010. Kumpulan Pedoman Pembelajaran Taman Kanak-kanak. Jakarta: Kemdiknas.

Khodijah, Siti dan Wismiarti. 2010. Panduan Pendidikan Sentra untuk PAUD: Sentra Seni. Jakarta: Pustaka Al-Falah.

Martono dan Retnowati, Tri Hartati. Jurnal Seni dan Pendidikan Seni "IMAJI" Vol. 7 No. 2. Pengaruh Setting Ruang Bermain terhadap Perkembangan Kreativitas pada Anak Usia Dini (Studi Kasus: Islamic Fullday Childcare and Preschool Ahsanu Amala di Yogyakarta). (http://jurnal_penelitian kreativitas_anak.html, diakses 15 Desember 2012).

Masiming, Zulfitriah. 2005. Jurnal SMARTek Vol. 7 No. 3. Pengaruh Metode Pembelajaran Permainan Bahasa terhadap Peningkatan Kretivitas Anak. (http://jurnal_penelitian_kreativitas_anak.html, diakses 10 September 2011).

Moeslichatoen R. 2005. Metode Pengajaran di Taman Kanak-kanak (pengembangan Kognitif, Bahasa, Kreativitas, Motorik, dan Emosional). Jakarta: Depdikbud.

Munandar, Utami. 2009. Pengembangan Kreativitas Anak Berbakat. Jakarta: Rineka Cipta.

Nugroho. 2011. It's Easy Olah Data dengan SPSS. Yogyakarta: Skripta Media Creative.

Sukardi S, Evan. 2010. Seni Keterampilan Anak. Jakarta: Universitas Terbuka. C S C O

Rachmawati, Yeni dan Kurniati, Euis. 2010. Strategi Pengembangan Kreativitas pada Anak Usia Taman Kanak-kanak. Jakarta: Kencana Prenada Media Group.

Sujiono, Yuliani Nurani. 2009. Konsep Dasar PAUD. Jakarta: Indeks.

Sujiono, Yuliani Nurani. 2010. Bermain Kreatif Berbasis Kecerdasan Jamak. Jakarta: Indeks.

Sugiyono. 2009. Metode Penelitian Pendidikan (Pendekatan Kuantitatif, Kualitatif, dan $R \& D$. Bandung: Alfabeta.

Suharnan. 2011. Kreativitas (Teori dan Pengembangan). Surabaya: Laros.

Sulistyorini, Binti. 2011. Perkembangan Kognitif dan Kreativitas Anak Usia 0-2 Tahun. Makalah Disajikan dalam Perkuliahan Prodi PG PAUD UNM. Malang September 2011.

Suyanto, Slamet. 2005. Konsep Dasar Pendidikan Anak Usia Dini. Jakarta: Depdiknas.

Wijana, Widarmi D. dkk. 2010. Kurikulum Pendidikan Anak Usia Dini. Jakarta: Universitas Terbuka.

Yus, Anita. 2011. Model Pendidikan Anak Usia Dini. Jakarta: Kencana Prenada Media Group.
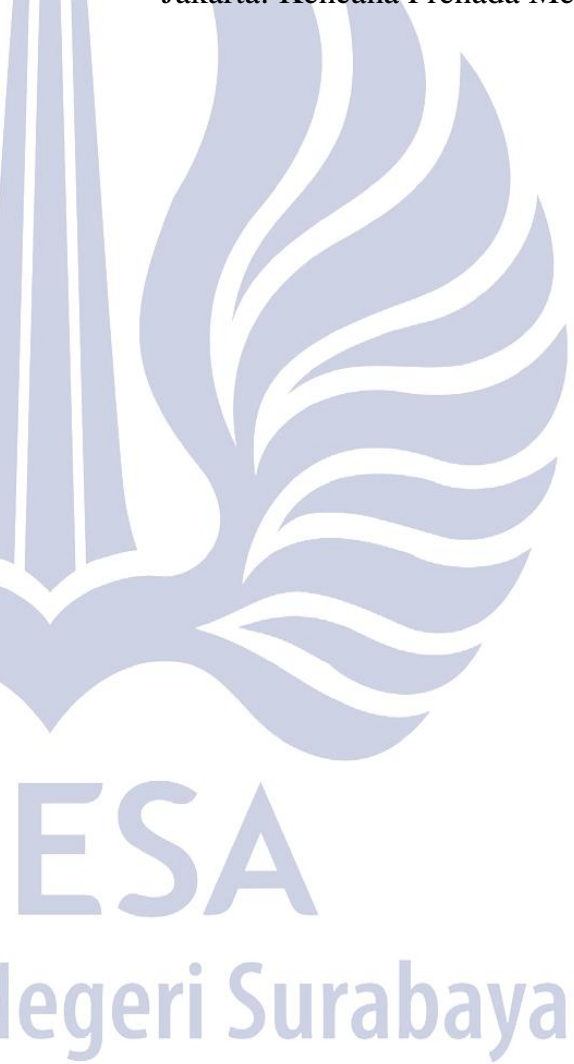